\title{
Burden of care and its impact on health-related quality of life of caregivers of individuals with spinal cord injury ${ }^{1}$
}

\author{
Paula Cristina Nogueira ${ }^{2}$ \\ Soraia Assad Nasbine Rabeh ${ }^{3}$ \\ Maria Helena Larcher Caliri ${ }^{4}$ \\ Rosana Aparecida Spadoti Dantas ${ }^{4}$ \\ Vanderlei José Haas ${ }^{5}$
}

\begin{abstract}
Objective: to analyze the impact and burden of care on the Health-Related Quality of Life (HRQOL) of caregivers of individuals with a spinal cord injury (SCI). Method: cross-sectional observational study carried out by reviewing medical records and applying questionnaires. The scale Short Form 36 (SF-36) was used to assess HRQOL and the Caregiver Burden Scale (CBScale) for care burden. Results were analyzed quantitatively. Most patients with SCIs were male, aged 35.4 years old on average, with a predominance of thoracic injuries followed by cervical injuries. Most caregivers were female aged 44.8 years old on average. Results: tetraplegia and secondary complications stand out among the clinical characteristics that contributed to greater care burden and worse HRQOL. Association between care burden with HRQOL revealed that the greater the burden the worse the HRQOL. Conclusion: Preventing care burden through strategies that prepare patients for hospital discharge, integrating the support network, and enabling access to health care services are interventions that could minimize the effects arising from care burden and contribute to improving HRQOL.
\end{abstract}

Descriptors: Quality of Life; Caregivers; Spinal Cord Injuries; Activities of Daily Living.

\footnotetext{
${ }^{1}$ Paper extracted from Doctoral Dissertation "Sobrecarga do cuidado e qualidade de vida relacionada à saúde de cuidadores de indivíduos com lesão medular", presented to Escola de Enfermagem de Ribeirão Preto, Universidade de São Paulo, WHO Collaborating Centre for Nursing Research Development, Brazil.

2 Post-doctoral fellow, Escola de Enfermagem de Ribeirão Preto, Universidade de São Paulo, WHO Collaborating Centre for Nursing Research Development, Brazil.

${ }^{3}$ Professor, Escola de Enfermagem de Ribeirão Preto, Universidade de São Paulo, WHO Collaborating Centre for Nursing Research Development, Brazil.

${ }^{4}$ PhD, Associate Professor, Escola de Enfermagem de Ribeirão Preto, Universidade de São Paulo, WHO Collaborating Centre for Nursing Research Development, Brazil.

${ }^{5}$ PhD, Visiting Professor, Universidade Federal do Triângulo Mineiro, Brazil.
} 


\section{Sobrecarga do cuidado e impacto na qualidade de vida relacionada à saúde de cuidadores de indivíduos com lesão medular}

Objetivo: analisar a sobrecarga do cuidado e impacto na Qualidade de Vida Relacionada à Saúde (QVRS) dos cuidadores de indivíduos com lesão medular traumática (LMT). Método: este é um estudo observacional, de corte transversal, realizado por revisão de prontuários e aplicação de questionários. Foram utilizadas as escalas Short Form 36 (SF-36) para avaliar a QVRS, Caregiver Burden Scale (CBScale) para sobrecarga do cuidado, e os resultados foram analisados quantitativamente. A maioria dos indivíduos com LMT era do sexo masculino, com média de idade de 35,4 anos, com predomínio de lesão torácica, seguida de lesão cervical. A maioria dos cuidadores era do sexo feminino, com média de idade de 44,8 anos. Resultado: das características clínicas que contribuíram para maior sobrecarga do cuidado e pior QVRS destacaram-se indivíduos com tetraplegia e com complicações secundárias. Ao associar a sobrecarga do cuidado com a QVRS, obteve-se que quanto maior a sobrecarga pior a QVRS. Conclusão: prevenir a sobrecarga do cuidado por meio de estratégias de preparo para alta, integração da rede de apoio e acesso a serviços de saúde, poderia minimizar os efeitos da sobrecarga do cuidado e contribuir para melhor QVRS.

Descritores: Qualidade de Vida; Cuidadores; Traumatismos da Medula Espinhal; Atividades Cotidianas.

\section{Sobrecarga del cuidado e impacto en la calidad de vida relacionada a la salud de los cuidadores de individuos con lesión medular}

Objetivo: análisis del sobrecarga del cuidado e impacto en la Calidad de Vida Relacionada a la Salud (CVRS), de los cuidadores de individuos con lesión medular traumática (LME). Método: estudio observacional, de corte transversal, realizado por revisión de prontuarios y aplicación de cuestionarios. Fueron utilizadas las escalas de Short Form 36 (SF-36) para evaluar la CVRS, Caregiver Burden Scale (CBScale) para Sobrecarga del cuidado y los resultados fueron analizados cuantitativamente. La mayoría de los individuos con LM era del sexo masculino, con media de edad de 35,4 años, con predominio de lesión torácica seguida de lesión cervical. La mayoría de los cuidadores era del sexo femenino, con media de edad de 44,8 años. Resultado: de las características clínicas que aportaron para mayor sobrecarga del cuidado y peor CVRS se destacaron individuos cuadripléjicos y con complicaciones secundarias. Al asociar la sobrecarga del cuidado con la CVRS se logró que cuanto mayor la sobrecarga peor a CVRS. Conclusión: precaver la sobrecarga del cuidado por medio de estrategias de adorno para alta, integración de la red de apoyo y acceso a servicios de salud, podrían minimizar los efectos de la sobrecarga del cuidado y aportar para una mejor CVRS.

Descriptores: Calidad de Vida; Cuidadores; Traumatismos de la Médula Espinal; Actividades cotidianas.

\section{Introduction}

A spinal cord injury (SCI) is a complex event that causes biopsychosocial changes that can influence the health and Quality of Life (QOL) of the patient and his/ her family caregiver providing care at home.

According to the World Health Organization (WHO), QOL is the perception of individuals concerning their position in life, cultural context, and system of values attributed to objectives, expectations, standards and concerns. This definition includes six main domains: physical health, psychological state, level of independence, social relationships, environmental characteristics, and spiritual pattern ${ }^{(1)}$.

Health-Related Quality of Life (HRQOL) has been used in the field to differentiate $\mathrm{QOL}$ in the generic sense. It is considered synonymous with the term "self-perceived health status", which contains three domains: the physical, psychological and social. The physical domain is related to aspects of functional capacity and work capacity. The psychological domain is related to satisfaction, well-being, self-esteem, anxiety 
and depression. The social domain includes aspects concerning rehabilitation for work, leisure, social and family interaction(2).

Research centers worldwide have conducted studies addressing the QOL of people with chronic health conditions in order to reveal the QOL phenomenon and promote interventions to improve the QOL of these individuals. This strategy is extended to people with $\mathrm{SCI}^{(3)}$. The QOL of an individual after an SCI depends on various factors, among them: multidisciplinary care and preparedness for care to be continued at home, as well as the participation of patients in rehabilitation programs.

The reduced functional capacity of an individual after an SCI compromises not only the patient's QOL and HRQOL. There is also an impact on the family, which is required to restructure itself to provide care to the disabled family member, possibly leading to great psychological and social impact on both the patient and his/her close family.

Burden refers to the impact that care provided in physical, psychological, social and financial terms causes on the life of a caregiver of a sick individual unable to perform Activities of Daily Life (ADL). Care burden is a term frequently used for caregivers who provide informal care, that is, they do not have an educational background in the health field and are not paid for providing such care ${ }^{(4)}$.

Measuring the care burden and HRQOL of caregivers of individuals with an SCI is extremely important if considered that such conditions strongly impact the lives of these individuals in social, psychological and emotional terms, in addition to the physical/functional sphere.

Even though the disease affects the entire family, one member, the primary caregiver, is responsible for providing the patient with physical, emotional and even financial care. The impact of chronic stress may lead to physical and psychological problems, which in turn may influence the care provided ${ }^{(4)}$. Special attention paid to the caregiver can improve his/her QOL, as well as that of the patient and even the entire family. Not only the QOL of patients, but also that of the caregiver may be affected by problems and burden faced by caregivers due to the care provided and its consequences(5).

Seeking to support advancement of knowledge on this subject, this study assesses care burden and the impact on the HRQOL of caregivers providing care to individuals with SCIs.

\section{Method}

This observational and cross-sectional study of a descriptive nature was submitted to and approved by an Ethics Research Committee (Process No. 3034/2009).

First, the medical records available in the health facilities affiliated with the Brazilian Unified Health System (SUS) in Ribeirão Preto, SP, Brazil were consulted to identify the potential participants. Afterwards, the researcher visited the individuals and applied the questionnaire Short Form 36 (SF-36) ${ }^{(6)}$ to assess HRQOL and the Caregiver Burden Scale (CBScale) ${ }^{(4)}$ to identify care burden. Both instruments were validated in Brazil.

The SF-36 is a generic instrument used to evaluate HRQOL, composed of 36 items, divided into eight domains (functional capacity, physical aspects, pain, health condition, vitality, social aspects, emotional aspects and mental health) assessed on a scale of zero to 100 (higher values indicate better HRQOL in the corresponding domain)(6). The CBScale is an instrument composed of 22 items divided into five domains (general strain, isolation, disappointment, emotional involvement, and environment) evaluated separately or jointly to obtain a single value for caregiver burden. The scale's total score ranges from 22 to 88 ; higher values indicate greater burden ${ }^{(4)}$.

The inclusion criteria for individuals with SCI to participate in the study included: being a resident of Ribeirão Preto and of the region belonging to the Regional Department of Health (DSR XIII); being able to understand and respond to the study's questions; having been affected by SCI from December 1998 to December 2008 and cared for by heath services affiliated with the SUS; being 18 years old or older at the time of data collection. Inclusion criteria concerning the caregivers were: individuals considered to be family members and indicated by the individuals with SCI as being their primary caregivers. The medical records of the individuals with SCI were used to select the individuals with SCI and 102 met the inclusion criteria. Of these, 32 were excluded (13 due to death, 15 were not found at the address and telephone number recorded in the medical file, and four had moved to a city outside of the area covered by the DRS XIII), totaling 70 individuals with SCI. Eleven of these reported no caregivers and being independent in the performance of ADLs. Hence, the final population was comprised of 59 individuals with $\mathrm{SCI}$ and their respective caregivers. 
Data were collected after the study's objectives were clarified and the participants consented by signing free and informed consent forms.

The Statistical Package for the Social Sciences (SPSS) version 15.0 was used for data analysis. The Student $t$ test was used to compare the averages among the groups categorized in qualitative variables. The Mann-Whitney and Kruskal-Wallis rank tests were used when the $t$ test and ANOVA requirements were not met (normality for small groups $\mathrm{n}<30$ ). Pearson's correlation coefficient was employed in the bivariate analysis of quantitative variables ${ }^{(7)}$. In regard to the classification used in this study to interpret the strength of correlations (values of " $r$ "); we used the classification that considers values up to 0.30 to have a weak correlation and little clinical applicability, even when statistically significant; values between 0.30 and 0.50 were held to be of moderate magnitude; and values above 0.50 were considered to be of strong magnitude ${ }^{(7)}$.

\section{Results}

Of the 59 individuals with SCI living in the area covered by the DRS XII, 52 (88.2\%) were men and $38(64.4 \%)$ were aged between 20 and 39 years old, with an average age of 37 years old $(S D=10.6)$. The main causes of trauma were: motor vehicle accidents $(22 / 37.3 \%)$ and firearms $(17 / 22 \%)$. A total of 31
$(52.5 \%)$ individuals had thoracic injuries while 43 $(72.8 \%)$ became paraplegic and 16 (27.2\%) became tetraplegic; 32 (54.3\%) developed some secondary complication while pressure ulcers (PU) were the most prevalent complication followed by urinary tract infections.

A total of $53(89.8 \%)$ caregivers were women: $22(37.3 \%)$ were the spouses, $14(23.7 \%)$ mothers, and nine $(15.3 \%)$ were sisters. The average age was 44.8 years old $(S D=14.7), 44(74.6 \%)$ were married, while $38(64.4 \%)$ had a low educational level. Twenty (33.9\%) of these had incomplete primary school and $18(30.5 \%)$ had completed primary school. Twentythree caregivers (39\%) quit their jobs to care for the individuals with SCI at home. The caregivers mentioned various care activities provided on a daily basis, from helping the more dependent individuals to perform ADLs and preparing food, to accompanying the less dependent individuals in going to medical consultations.

In regard to health problems, 29 (49.2\%) caregivers reported some health problems while hypertension (18/30.5\%) and depression (6/10\%) were the conditions most frequently reported.

Tables 1 and 2 present the associations between the clinical characteristics of individuals with SCI and the caregivers' care burden and HRQOL.

Table 1 shows the associations of consequences concerning the level of injury with care burden.

Table 1 - Comparison of location and scale measures and variability of burden scores, considering the consequences of SCI neurological level. Ribeirão Preto, SP, Brazil, 2010

\begin{tabular}{|c|c|c|c|c|c|}
\hline \multirow{3}{*}{ CBScale } & \multicolumn{5}{|c|}{ Tetraplegia } \\
\hline & \multicolumn{2}{|c|}{ Yes $(n=32)$} & \multicolumn{2}{|c|}{ No $(n=27)$} & \multirow{2}{*}{$\mathbf{p}^{*}$} \\
\hline & $\bar{\chi}(\mathrm{SD})$ & Median & $\bar{\chi}(\mathrm{SD})$ & Median & \\
\hline Overall burden & $2.05(0.53)$ & 1.81 & $1.81(0.71)$ & 1.56 & 0.04 \\
\hline \multicolumn{6}{|l|}{ Domains } \\
\hline General strain & $2.24(0.69)$ & 2.12 & $1.82(0.83)$ & 1.50 & 0.02 \\
\hline Isolation & $1.89(0.81)$ & 1.66 & $1.56(0.77)$ & 1.33 & 0.06 \\
\hline Disappointment & $2.08(0.65)$ & 2.00 & $1.88(0.83)$ & 1.80 & 0.24 \\
\hline Emotional Involvement & $1.64(0.71)$ & 1.33 & $1.57(0.88)$ & 1.00 & 0.29 \\
\hline Environment & $2.08(0.76)$ & 2.00 & $2.16(0.83)$ & 2.00 & 0.80 \\
\hline
\end{tabular}

*Mann-Whitney test

The results show that care burden was greater in four of the five domains and also in overall burden when in the presence of tetraplegia, with values of $p<0.05$.
Table 2 presents the associations of complications after SCI with care burden. 
Table 2 - Comparison of location and scale measures and variability of burden scores considering complications experienced by individuals with SCI. Ribeirão Preto, SP, Brazil, 2010

\begin{tabular}{|c|c|c|c|c|c|}
\hline \multirow{3}{*}{ CBScale } & \multicolumn{5}{|c|}{ Complications } \\
\hline & \multicolumn{2}{|c|}{ Yes $(n=32)$} & \multicolumn{2}{|c|}{ No $(n=27)$} & \multirow{2}{*}{$\mathbf{p}^{*}$} \\
\hline & $\bar{\chi}(\mathrm{SD})$ & Median & $\bar{\chi}(\mathrm{SD})$ & Median & \\
\hline Overall burden & $1.93(0.66)$ & 1.75 & $1.81(0.68)$ & 1.59 & 0.49 \\
\hline \multicolumn{6}{|l|}{ Domains } \\
\hline General strain & $1.94(0.82)$ & 1.75 & $1.91(0.82)$ & 1.62 & 0.90 \\
\hline Isolation & $1.79(0.79)$ & 1.66 & $1.47(0.76)$ & 1.00 & 0.12 \\
\hline Disappointment & $2.06(0.83)$ & 2.00 & $1.78(0.71)$ & 1.60 & 0.18 \\
\hline Emotional involvement & $1.57(0.86)$ & 1.00 & $1.62(0.82)$ & 1.33 & 0.84 \\
\hline Environment & $2.18(0.85)$ & 2.00 & $2.20(0.75)$ & 2.00 & 0.71 \\
\hline
\end{tabular}

In regard to the presence of complications, we verified that the averages of three of the five domains on the CBScale and overall burden were higher when the individual with SCI experienced some complication though these differences were not statistically significant.

The results presented in tables 3 and 4 refer to the associations of consequences of SCI with the HRQOL of the caregivers.

Table 3 - Comparison of location and scale measures and variability of the caregivers' scores in the HRQOL domains, considering the consequences of the neurological level of the individual with SCI. Ribeirão Preto, SP, Brazil, 2010

\begin{tabular}{|c|c|c|c|c|c|}
\hline \multirow{3}{*}{$\begin{array}{l}\text { HRQOL } \\
\text { Domains }\end{array}$} & \multicolumn{5}{|c|}{ Tetraplegia } \\
\hline & \multicolumn{2}{|c|}{ Yes $(n=32)$} & \multicolumn{2}{|c|}{ No $(n=27)$} & \multirow{2}{*}{$\mathbf{p}^{*}$} \\
\hline & $\bar{\chi}(\mathrm{SD})$ & Median & $\bar{\chi}(\mathrm{SD})$ & Median & \\
\hline Functional capacity & $64.00(24.5)$ & 65.00 & $71.25(28.0)$ & 80.00 & 0.23 \\
\hline Physical aspects & $33.33(37.4)$ & 25.00 & $58.52(41.0)$ & 75.00 & 0.04 \\
\hline Pain & $44.00(19.0)$ & 42.00 & $63.00(24.6)$ & 62.00 & 0.01 \\
\hline Overall health condition & $62.60(18.6)$ & 62.00 & $66.02(23.2)$ & 67.00 & 0.51 \\
\hline Vitality & $59.66(20.6)$ & 55.00 & $59.43(27.6)$ & 62.50 & 0.99 \\
\hline Social aspects & $67.50(29.4)$ & 87.50 & $73.57(30.3)$ & 87.50 & 0.36 \\
\hline Emotional aspects & $48.89(43.4)$ & 33.33 & $64.39(43.9)$ & 100.0 & 0.22 \\
\hline Mental health & $69.33(18.9)$ & 68.00 & $65.54(23.9)$ & 70.00 & 0.69 \\
\hline
\end{tabular}

*Mann-Whitney test

The medians show that the HRQOL was more compromised among tetraplegic individuals in virtually all domains of the SF-36, especially in relation to the
Physical Aspects (median 25.00; p<0.05) and Pain (median 42.00; $\mathrm{p}<0.05$ ) domains.

Table 4 - Comparisons of location and scales measures and variability of the caregivers' scores in the HRQOL domains, considering the presence of complications in individuals with SCI. Ribeirão Preto, SP, Brazil, 2010

\begin{tabular}{|c|c|c|c|c|c|}
\hline \multirow{3}{*}{ Domains } & \multicolumn{5}{|c|}{ Complications } \\
\hline & \multicolumn{2}{|c|}{ Yes $(n=32)$} & \multicolumn{2}{|c|}{ No $(n=27)$} & \multirow{2}{*}{$\mathbf{p}^{*}$} \\
\hline & $\bar{\chi}(\mathrm{SD})$ & Median & $\bar{\chi}(\mathrm{SD})$ & Median & \\
\hline Functional capacity & $68.28(27.4)$ & 75.00 & $70.74(27.3)$ & 80.00 & 0.73 \\
\hline Physical aspects & $48.44(41.1)$ & 50.00 & $56.48(41.9)$ & 75.00 & 0.46 \\
\hline Pain & $56.16(21.7)$ & 52.00 & $60.55(27.9)$ & 61.00 & 0.50 \\
\hline Overall health conditions & $61.87(18.9)$ & 57.00 & $69.04(24.9)$ & 77.00 & 0.22 \\
\hline Vitality & $58.44(25.1)$ & 75.00 & $60.74(27.1)$ & 65.00 & 0.73 \\
\hline Social aspects & $67.58(30.8)$ & 55.00 & $77.31(28.6)$ & 87.50 & 0.21 \\
\hline Emotional aspects & $54.17(46.2)$ & 66.66 & $67.90(40.8)$ & 100.0 & 0.23 \\
\hline Mental health & $67.50(23.3)$ & 66.00 & $65.33(22.2)$ & 72.00 & 0.72 \\
\hline
\end{tabular}

*Student $t$ test 
When the individual with SCI experienced some complication, the caregiver's HRQOL worsened, with the exception of the Mental Health domain. However, the differences between the averages of groups with and without complications were not statistically significant.

Table 5 presents the results of correlations between caregiver care burden and HRQOL.

Table 5 - Correlations between the burden and HRQOL of caregivers providing care to individuals with SCI. Ribeirão Preto, SP, Brazil, 2010

\begin{tabular}{|c|c|c|c|c|c|c|}
\hline \multirow{3}{*}{ HRQOL domains } & \multicolumn{6}{|c|}{ Care burden } \\
\hline & General strain & Isolation & Disappointment & $\begin{array}{c}\text { Emotional } \\
\text { involvement }\end{array}$ & Environment & Overall burden \\
\hline & $\mathbf{r}$ & $\mathbf{r}$ & $\mathbf{r}$ & $\mathbf{r}$ & $\mathbf{r}$ & $\mathbf{r}$ \\
\hline Functional capacity & $-0.34^{\dagger}$ & $-0.30^{*}$ & -0.18 & -0.12 & -0.08 & $-0.28^{*}$ \\
\hline Physical aspects & $-0.52^{\dagger}$ & $-0.41^{\dagger}$ & $-0.29^{*}$ & -0.23 & -0.15 & $-0.44^{\dagger}$ \\
\hline Pain & $-0.69^{\dagger}$ & $-0.54^{\dagger}$ & $-0.53^{\dagger}$ & $-0.40^{\dagger}$ & $-0.27^{*}$ & $-0.64^{\dagger}$ \\
\hline Overall health condition & $-0.30^{*}$ & $-0.25^{*}$ & $-0.27^{*}$ & -0.13 & -0.23 & $-0.30^{*}$ \\
\hline Vitality & $-0.53^{\dagger}$ & $-0.48^{\dagger}$ & $-0.44^{\dagger}$ & $-0.26^{*}$ & $-0.30^{*}$ & $-0.52^{\dagger}$ \\
\hline Social aspects & $-0.66^{\dagger}$ & $-0.58^{\dagger}$ & $-0.58^{\dagger}$ & $-0.34^{\dagger}$ & $-0.41^{\dagger}$ & $-0.66^{\dagger}$ \\
\hline Emotional aspects & $-0.50^{\dagger}$ & $-0.48^{\dagger}$ & $-0.30^{*}$ & -0.09 & -0.16 & $-0.42^{\dagger}$ \\
\hline Mental Health & $-0.52^{\dagger}$ & $-0.43^{\dagger}$ & $-0.51^{\dagger}$ & -0.24 & $-0.29^{*}$ & $-0.52^{\dagger}$ \\
\hline
\end{tabular}

$* \mathrm{p} \leq 0.05$

$+p \leq 0.01$

$r=$ Pearson's correlation

The analysis of the results of correlations between the caregivers' burden and HRQOL revealed that all the correlations were negative, indicating that the higher the burden, the worse was the caregiver's HRQOL.

The correlations were from moderate to strong and statistically significant for most domains. Strong correlation with r-values above 0.5 and $p \leq 0.01$ stood out.

\section{Discussions}

The socio-demographic profile of the study's participants corroborates that reported in the literature, which indicates that the population most affected by SCIs is young adult males aged between 18 and 35 years of age $\mathrm{e}^{(8-11)}$.

In relation to the causes of SCIs, violent acts have been observed in Brazil and in other parts of the world as a frequent causal factor ${ }^{(8-12)}$.

A Brazilian retrospective study was conducted in a tertiary university hospital in the interior of São Paulo, Brazil to verify the occurrence of PUs in patients with SCI hospitalized between 2000 and 2003. The results indicated, among other things, that SCI was mainly caused by firearms $(44.7 \%)$ followed by vehicular rollovers/crashes $(23.4 \%)^{(9)}$.

These results, as well as those reported by other studies, confirm that urban violence and auto and occupational accidents are important causes of disabilities in Brazil, especially in large and medium urban centers ${ }^{(8-12)}$.

Another determining factor in the identification of the magnitude of the problem and support for the planning of care provided to individuals with SCI is identifying the level of SCI, since that determines the expected functional capacity

The neurological exam that establishes the level of an SCI takes into account the lowest segment of the spinal cord that has intact motor and sensorial function. Injuries may be complete or incomplete. Complete injury involves the loss of all the motor and sensorial functions and reflexes below the spinal cord injury. In an incomplete injury, partial motor or sensorial function, or both functions, are preserved below the level of the spinal cord injury ${ }^{(13)}$.

Individuals with SCI lose their ability to move and control some body activities and reactions and can also lose sensitivity in some limbs. Such loss leads to a feeling of powerlessness that is a reflection of limitation and dependency.

Consequently, the individual becomes dependent on the caregiver for the performance of ADLs, especially in the first year after the injury. This is true especially among tetraplegic individuals; the higher the neurological level of injury the higher the level of dependency ${ }^{(14)}$.

The family caregiver experiences various situations while performing this role. First, there is a concern over the condition of the individual with SCI and with keeping 
him/her stable. At the same time, the caregiver needs to learn various specificities arising from SCIs, such as learning to provide care related to the bladder, intestines, breathing, how to check the skin daily and recognize signs of PUs. Hence, there are many adjustments in the caregiver's lifestyle to be implemented over time.

PUs stand out among the complications found in this study. Many studies addressing SCI report that PUs are the main complications experienced by these patients ${ }^{(8-9,15-16)}$. Such occurrences may be prevented or attenuated with follow-up in health units, ambulatories or rehabilitation services. Nonetheless, studies conducted in Ribeirão Preto report the persistence of this problem among this population ${ }^{(8-9,15,17)}$.

In regard to the socio-demographic and clinical characteristics of caregivers, many studies present similar results, which highlight the predominance of female caregivers who are married, aged 45 to 50 years old on average and with a low educational level(9,18-21).

This study's caregivers provided care from the beginning of the SCI. These findings reinforce the social role of women who have historically been recognized as the ones responsible for caring for the house, family and any sick family members.

Many factors have been considered in the literature, such as the risk of caregivers developing health problems. Factors include not only those related to the patient being under care, but also those factors inherent to the caregivers themselves, such as age, gender, kinship, and quality of their relationship with the patient ${ }^{(19,21-22)}$.

A study addressing caregivers of American veterans aiming to evaluate the impact of burden on the caregivers' HRQOL verified that burden worsened almost all the domains of HRQOL. When the authors compared objective and subjective care burden to the SF-36 domains, objective burden presented a stronger relationship with all the SF-36 domains, except for the Mental Health domain, which may be explained by the caregivers' low socio-economic status. This study's findings highlight that caregiver burden affected the caregivers' health, through the Vitality and Mental Health domains, which definitely resulted in reduced performance in the remaining health domains(23).

Another study of 50 individuals with SCI and their respective family caregivers assessed the $\mathrm{QOL}$ of the participants with the WHOQOL-Bref and the caregivers' burden with the Zarit Burden Inventory (ZIB). The study reported that care burden has a negative correlation with level of impairment, physical independency, mobility, social integration and $\mathrm{QOL}$ scores of the individuals with SCI, highlighting the Physical, Psychological, and Environmental domains ${ }^{(24)}$.

In a study conducted in Colombia, researchers assessed the most frequent needs of 37 family caregivers of individuals with SCI using an instrument with 27 questions subdivided into five scales and nine subscales (needs concerning emotional and economic aspects, physical and psychological health, sleep, respite, social support, information and support from the community). The results revealed that physical health, emotional and socio-economic needs where the subscales that most positively correlated with depression and burden(25).

Evidence reported in the literature shows that not only the patients but also their caregivers present needs after a SCI and if these are not properly heeded, they directly affect the caregivers' care burden and QOL.

Therefore, it is crucial that caregivers providing care to individuals with SCI at home be prepared through educational strategies because the task of providing care to a dependent adult is wearying and can put the caregiver's health at risk. Hence, nurses have the ethical and legal responsibility to plan educational actions to prepare both the individuals with SCI and their respective caregivers.

\section{Final considerations}

SCIs cause problems of a physical, psychosocial, emotional and economic nature, which affect not only the individual with the injury but his/her family, as well. These problems may lead to dissatisfaction with life and, consequently, reduce the QOL of both patient and caregiver.

Usually, caregivers are not prepared to take on the care and responsibility demanded. They are faced with a sudden and unexpected situation and need to be properly prepared to assume such responsibilities.

The individual with SCI and his/her respective caregiver need to be prepared for discharge as soon as possible during hospitalization. The process of providing supportive reception and clarifying doubts is necessary for the patient and caregiver to acquire knowledge and skills to adapt to the new life.

Social and support networks, access to rehabilitation centers and health services with professionals with updated knowledge concerning individuals with SCI and caregivers are all extremely important to the goal of minimizing complications arising from the injury and care burden. 


\section{References}

1. Fleck MPA. O instrumento de avaliação de qualidade de vida da Organização Mundial da Saúde (WHOQOL-100): características e perspectivas. Ciênc Saúde Coletiva. 2000;5(1):33-8.

2. Fayers PM.; Machin D. Scores and measurement: validity, reliability and sensitivity. Quality of life. Assessment, analisis and interpretation. Chichester (EN): John Wiley; 2007.

3. Vall J.; Braga VABB; Almeida PC. Estudo da qualidade de vida em pessoas com lesão medular traumática. Arq Neuropsiquiatr. 2006;64(2-B):451-5.

4. Medeiros MMC; Ferraz MB; Quaresma M; Menezes AP. Adaptação ao Contexto Cultural Brasileiro e Validação do Caregiver Burden scale. Rev Bras Reumatol. 1998;38(4):193-9.

5. Schulz R; Lustig A; Zdaniuk B; Martire LM; Czaja SJ; Perdomo $D$. Improving the quality of life of caregivers of persons with spinal cord injury: a randomized controlled trial. Rehabil Psychol. 2009;54(1):1-15.

6. Ciconelli RM; Ferraz MB; Santos W; Meinão I; Quaresma, MR. Tradução para o português e validação do questionário genérico de avaliação de qualidade de vida SF 36 (Brasil SF 36). Rev Bras Reumatol. 1999;39(3):143-50.

7. Ajzen J.; Fishbein M. Overview. In: Ajzen J.; Fishbein M. Understanding attitudes and predicting social behavior. New Jersey: Prentice-Hall; 1998.

8. Nogueira PC; Caliri MHL; Haas VJ. Profile of patients with spinal cord injuries and occurrence of pressure ulcer at a university hospital. Rev. Latino-Am. Enfermagem. 2006;14(3):372-7.

9. Rabeh SAN; Caliri MHL. Capacidade funcional em indivíduos com lesão de medula espinal. Acta Paul Enferm. 2010;23(3):321-7.

10. Vasconcelos ECLM; Riberto M. Caracterização clínica e das situações de fratura da coluna vertebral no município de Ribeirão Preto, propostas para um programa de prevenção do trauma raquimedular. Coluna/Columna. 2011;10(1):40-3.

11. Coura AS; França ISXde; Enders BC; Barbosa ML; Souza JRS. Functional disability of adult individuals with spinal cord injury and its association with socio-demographic characteristics. Rev. Latino-Am. Enfermagem. [periódico na Internet]. 2012; [acesso 27 ago 2012]. 20(1). Disponível em <http://www. scielo.br/scielo.php?script=sci_arttext\&pid=S0104$11692012000100012 \&$ lng=pt\&nrm=iso $>$. http://dx.doi. org/10.1590/S0104-11692012000100012.
12. Costa VSP; Melo MRAC; Garanhani ML; Fujisawa DS. Representações sociais da cadeira de rodas para a pessoa com lesão da medula espinhal. Rev. Latino-Am. Enfermagem. [periódico na Internet]. 2010; [acesso 27 ago 2012]. 18(4). Disponível em <http://www. scielo.br/scielo.php?script $=$ sci_arttext\&pid $=$ S0104$11692010000400014 \&$ Ing $=$ pt\&nrm=iso $>$. http://dx.doi. org/10.1590/S0104-11692010000400014.

13. American Spinal Injury. Association International Medical Society of Paraplegia. ASIA/IMSOP. Padrões internacionais para classificação neurológica e funcional de lesões na medula espinhal: revisado 1996. Chicago: ASIA; 1996.

14. Paralyzed Veterans of America. Outcomes following traumatic spinal cord injury: a clinical practice guideline for health-care professionals. (Clinical Practice Medicine: spinal cord medicine).USA: PVA; July 1999.

15. Carciononi M; Caliri MHL; Nascimento MS. Ocorrência de úlcera de pressão em indivíduos com lesão traumática da medula espinhal. REME. 2005;9(1):29-34.

16. Bruni DS, ;Strazzieri KC; Gumieiro MN; Giovanazzi R, Sá VG, Faro ACM. Aspectos fisiopatológicos e assistenciais de enfermagem na reabilitação da pessoa com lesão medular. Rev Esc Enferm USP. 2004;38(1):71-9.

17. Nogueira PC, Caliri MHL, Santos CB. Fatores de risco e medidas preventivas para úlcera de pressão no lesado medular. Experiência da equipe de enfermagem do HCFMRP-USP. Medicina. (Ribeirão Preto) 2002;35(1):1423.

18. Blanes L, Mis C, Ferreira LM. Health-related quality of life of primary caregivers of persons with paraplegia. Spinal Cord. 2007;45:399-403.

19. Faro ACM. Atividades realizadas no domicílio pelo cuidador familiar da pessoa com lesão medular. Rev Paul Enferm. 2001;20(2):33-43.

20. Lucke KT, Coccia H, Goode, JS, Lucke JF. Quality of life in spinal cord injured individuals and their caregivers during the initial 6 months following rehabilitation. Qual Life Res. 2004;13:97-110.

21. Amendola F, Oliveira MAC, Alvarenga MRM. Influência do apoio social na qualidade de vida do cuidador familiar de pessoas com dependência. Rev Esc Enferm USP. 2011;45(4):884-9.

22. Rees J, O`Boyle C, McDonagh R. Quality of life: impact of chronic illness on the partner. J Royal Soc Med. 2001;94:563-6.

23. Hughes SL, Giobbie-Hurder A, Weaver FM, Kubal JD, Henderson W. Relationship Between Caregiver Burden and Health-Related Quality of Life. Gerontologist. 1999;39(5):534-45. 
24. Naveen S. Quality of life in traumatic spinal cord injured and caregiver burden. [dissertação mestrado]. Bangarole - India: Rajiv Gandhi University of Health Sciences; 2007. 122 p.

25. Arango-Lasprilla JC, Plaza SLO, Drew A, Romero JLP, Pizarro JAA, Francis K, Kreutzer J. NeuroRehabilitation. Family needs and psychosocial functioning of caregivers of individuals with spinal cord injury from Colombia, South America. NeuroRehabilitation. 2010;27:83-93. 